\title{
Mapping Landscape Values and Conflicts through the Optics of Different User Groups
}

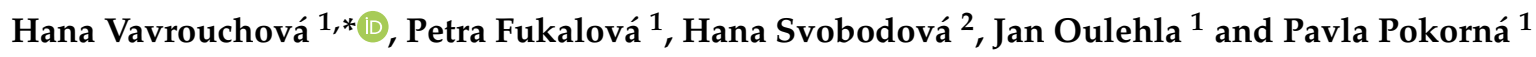 \\ 1 Department of Applied and Landscape Ecology, Faculty of AgriSciences, Mendel University in Brno, \\ Zemedelska 1, 61300 Brno, Czech Republic; petra.fukalova@mendelu.cz (P.F.); jan.oulehla@mendelu.cz (J.O.); \\ pavla.pokorna@mendelu.cz (P.P.) \\ 2 Department of Geography, Faculty of Education, Masaryk University, Porici 7, 60300 Brno, Czech Republic; \\ 67632@mail.muni.cz \\ * Correspondence: hana.vavrouchova@mendelu.cz
}

Citation: Vavrouchová, H.; Fukalová,

P.; Svobodová, H.; Oulehla, J.;

Pokorná, P. Mapping Landscape

Values and Conflicts through the Optics of Different User Groups. Land 2021, 10, 1306. https://doi.org/ 10.3390/land10121306

Academic Editors: Bastian Bertzky, Colleen Corrigan and Susan Snyman

Received: 20 October 2021

Accepted: 25 November 2021

Published: 26 November 2021

Publisher's Note: MDPI stays neutral with regard to jurisdictional claims in published maps and institutional affiliations.

Copyright: (c) 2021 by the authors. Licensee MDPI, Basel, Switzerland This article is an open access article distributed under the terms and conditions of the Creative Commons Attribution (CC BY) license (https:// creativecommons.org/licenses/by/ $4.0 /)$.

\begin{abstract}
The paper presents the results of the study on participative mapping of landscape values and conflicts and a subsequent interpretation of the indicated localities from respondents' point of view. The study focused on younger groups of landscape users-lower-secondary-school students (aged 11-15) and university students (aged 20-25) - in comparison with experts' points of view. The research presumed that the perception of landscape values and issues are determined by age, level of education and by experience in the field. The study was conducted in the southeastern area of the Czech Republic $\left(49^{\circ} \mathrm{N}, 16^{\circ} \mathrm{E}\right)$ via online data collection. Based on the obtained records, we conclude that, in terms of the typology of the valuable and problematic locations, the individual groups of respondents did not differ significantly and the selection of location types was similar across all groups. Lower-secondary-school students rather identified cultural values associated with everyday activities, and the descriptions contained emotional overtones. University students preferred natural values associated with formal values based on general consensus or conflicts associated with society-wide impacts. The experts base served as the benchmark for other groups.
\end{abstract}

Keywords: landscape evaluation; participatory mapping; landscape perception; youth participation

\section{Introduction}

The impact of human society on the landscape is indisputable. It is particularly negative in the long run, especially when it comes to economic development. The landscape is often transformed in a negative and irrevocable way. This is caused by insufficient consideration of the impact of local activities on a regional and national scale. A society also lacks awareness of the link between human activities and the functioning of the landscape (e.g., the link between the expansion of built-up areas and the reduction of the water retention capability of the landscape or the increase in traffic intensity). Protection and effective land management are complicated by social non-perception of a stable landscape mosaic as a value in itself. A society without direct links to the land has lost its knowledge of the natural development of the landscape, and this is reflected in thought patterns lacking continuity in the planning of spatial development. This negative trend in the use of land is also substantiated by the Global Environment Outlook 6 report [1], which identifies spatial planning and soil management based on a participatory approach and bottom-up initiatives as appropriate solution tools.

It is a good idea to encourage people to adopt an approach to the utilization of landscape that is based on the knowledge and understanding of the links between human activities and landscape stability. Support of such a responsible approach to the landscape can be initiated on the level of primary (or even pre-primary) education. Many tools can be used to facilitate the understanding of the impact of anthropogenic activities on the environment. One of them could be activities for students based on the identification of 
high-value and problematic locations in the landscape in which they live or which they interpret by using available sources (strategic planning tools, maps and field surveys). This approach was applied in cooperation with primary and secondary schools and with universities in the South Moravian Region (Czech Republic), and the result is a specialized map titled "High-value and Problematic Locations as Seen through the Optics of Their Future Users". This map is based on the identification of specific locations which the students consider to be of high value or problematic. A "high-value" location in this context means a place in a built-up area of or a place in the open landscape which can be considered as having great importance from the natural or social point of view-e.g., a preserved part of the landscape, a site with typical landscape character, a popular place in the landscape or a meeting place. A "problematic" location is defined in this context as a place in a built-up area or a place in the open landscape which is perceived as being disruptive as a result of human activity. Such locations may be, for example, sites that are deficient in terms of their appearance or functionality or places that disrupt the character of the landscape, pollute the territory or prevent the migration of animals. The research question was based on the assumption that the perception of landscape values and conflicts is determined by age, level of education and by experience in the field. The hypothesis was based on the presumption that the younger students would identify different types of localities than the university students (as well as experts) and that younger students' point of view would be simpler (that is, they would identify only obvious values and conflicts). Our goal is to document and compare the approaches of different groups of students to the perception of values and problems in the landscape (we used the experts' optics of landscape values and problems as the benchmark for others groups).

The purpose of recording the locations on a map, apart from identifying, describing and highlighting these locations, is to find out how the landscape and its value are perceived and interpreted by pupils under 15 years of age, and to compare their views with the perspective of university students (up to the age of 25) who specialize in a relevant field of study and with the opinion of experts (university lecturers). An important part of the study was also the proposing of measures for the future development of the landscape. The results of the research intended to help decision-makers to understand, design and promote environmentally sustainable and socially resilient urban and rural landscapes [2]. It is generally believed that, when partnerships with civil society (in our case partnership with decision-makers and pupils from local schools) are created, members of the public become engaged in defining and solving problems [3]. Another purpose of the study is to teach the young generation to see the landscape as a value in the protection and management of which they can get practically involved. The key importance of participatory scenario planning in the learning process is corroborated by Poskitt et al. [4], who emphasize the knowledge gained through the interaction.

\section{Literature Review}

Participative planning, which consists of a collaboration of the administrative sphere with the public, is a very effective form of strategic management and is being increasingly utilized in practice. Experience with involving the public in decisions concerning changes to the use of land, including visualization by means of GIS, has been described by a number of authors [5-8]. There are numerous studies based on public participation geographic information systems (PPGIS), where "spatially explicit perception and evaluation statements" are obtained from the parties involved and subsequently integrated with existing land cover maps [9]. The participants create lines and polygons or situate points within the cartographic space and in this way represent specific attributes or features of the landscape, such as historical sites, areas of high natural value or locations that are significant to them in other ways, including in the context of change processes [10,11]. These studies are also used to understand how people identify and describe landscape values in space [12]. Št'astná and Vaishar [13] point out the difference between the perception of landscape values from an academic point of view and from the point of view of the actual users 
of the land and emphasize the need to interpret values in cooperation with the relevant population groups (residents, tourists, entrepreneurs, etc.). This thesis is also supported by other authors $[14,15]$.

Participation and its methods, particularly regarding the ways of facilitating the involvement of the public in planning processes beyond the legal minimum of public notifications and hearings, were assessed, for instance, by Eiter and Lange Vik [16]. Spencer [17] describes a method based on the use of group discussions, plenary discussions and workshops with the aim of identifying local values, issues and knowledge. The importance of a meaningful dialogue and active field surveys during participative planning is emphasized by Clemetsen et al. [18] and the use of verbal methods when resolving issues in the landscape in the form of meetings and discussions are also recommended by Larsson et al. [19]. Visual aids, such as drawings, 3D illustrations, photographs and maps, as well as the presentation of scenarios, as described by Michelin et al. [20], are also often suitable for stimulating discussion. Ramos [21] combines visual and written verbal aids when describing future aspirations and scenarios. Individual methods differ in their scale and degree of formalization and also as to whether the landscape representations take place only as part of indoor discussions or whether outdoor field trips are utilized as well. However, all of these methods have in common the fact that they are used to characterize and assess the landscape, and their purpose is to "improve the ability of people to express their opinions and perspectives" [22]. This process may increase awareness, as well as create understanding, which are both conditions for the expression of people's opinions.

A very effective form of participative planning is participative mapping. The practical output of this method of involving the public may be the so-called emotional maps, which usually cover a wide range of aspects of spatial development, with the option of a narrower focus (e.g., on assessment of the attractiveness or safety of selected locations, on the identification of meeting places, or on the evaluation of proposals for future development). It is useful to combine this activity with spatial visualization, using GIS tools. In relation to this, Pánek [23] introduced the term "geoparticipation" for tools for spatial visualization of social preferences and pointed out the transformation of the public's role from passive subjects for whom the space is created to active co-creators of the community strategy. Pánek [24] also develops the concept of emotional maps from the theoreticalmethodological aspect, as well as in terms of its practical application. The concept of citizen science, which is based on collaboration between the scientific community and the general public, also arises from similar principles. The key thing here is the involvement of motivated volunteers in scientific projects from various areas, with the goal of mutual expansion of the knowledge of all participants. This topic is discussed on a scholarly level, for instance, by Trojan et al. [25], or by Lee et al. [26], who confirm the great importance of involving the public in environmental protection and issues, such as the monitoring of geohazards, with the involvement taking place during the formulating of research questions, as well as during the collection and analysis of data. Numerous local map applications for making spatial records of issues connected with public spaces are based on the supposition that the public is not indifferent to the condition and development of the area they live in. These issues are subsequently addressed in cooperation with local authorities.

The methods of participation can generally be divided into two categories, depending on whether they focus on the public in general or on specific groups of users of the land. This subsequently determines the tools to be used for involving the relevant subjects. Posters, information leaflets and personal letters are measures focusing on the general public. Although the distribution of posters may be time-consuming, it is probable that more people will be affected by one poster than by a personal letter or a folder with information sent to households. For municipalities or planning areas with a large population, sending individual letters also means considerable additional costs. This is why these measures would be more appropriate for smaller communities or planning areas. As regards involving specific groups of participants, personal forms of cooperation under 
the auspices of the mayor or some other territorial manager (e.g., the manager of a Local Action Group) are more appropriate.

It is also important to mention the link between participatory planning and the possibility of community quality of life increases. The significant role of the local community plan in life quality management is pointed out by Reference [27]. The interaction between the community and local authority is essential, as well as the balanced space of each sector involved in the plan. Reference [28] puts public participation in direct relation to the quality of life. Active participation in urban planning increases the rate of adaptation to the real needs and also the acceptance of planned changes.

The importance of using participatory planning as a tool of local governance in the process of creating a responsible development strategy is confirmed by Hedelin et al. [29], but their analysis of the documents leads to the conclusion that there is insufficient "multivalue perspective within a democratic process and [...] integration across organizations within a governance system". They also highlight the overwhelming preponderance of expert opinions overlay opinions. The cause of this situation may be insufficient knowledge communication between the scientific and political spheres and the subsequent lack of sharing of this knowledge with the public. Competent involvement of the public requires basic familiarity with legal measures and knowledge of the relations within the landscape. It is a good idea to create conditions for learning these skills already at primary and secondary schools. This applies to the process of learning as well as to practical involvement of students in the decisions regarding spatial development (to the appropriate extent). Most forms of participative planning previously involved the adult population [30], and there is less research on the perception of the landscape by children and young people.

Projects by pupils, questionnaire surveys and video recordings for young people increase representativeness by focusing on these specific groups of youngsters and their parents. Eiter and Lange Vik [16] used a questionnaire in their study to obtain information from parents, and the project titled "Pupils' project and Youth cameras" specifically focused on juvenile persons (i.e., pupils). The utilization of visual tools is particularly beneficial in relation to measures focusing on young people. Visual tools may be useful for stimulation of inputs and may supplement verbal tools and methods. This may support verbal and visualization skills, particularly in the younger age categories, by helping pupils present their inputs appropriately. Findings from the involvement of children (or pupils and students at primary and secondary schools) in the planning of the utilization of space in all stages of the process (analytical-synthetic evaluation, proposal of a solution and its implementation, monitoring of proposed measures) are presented, among others, by Özdemir [31]. The author highlights the benefits of involving children in creating their environment and facilitating their adaptation to the changes in their surroundings. Puolamäki [32] also published a similar methodological approach to the identification of cultural values by children. Specific experience with creating emotional maps in the school environment (on the level of upper secondary schools) was published by Novotná and Havelková [33]. The results of References [34,35] strongly support the idea that children and teenagers perceive their environment differently from adults (for surveys, see, for instance, References [36,37]). Understanding the perspective of young people is particularly relevant with regard to the fact that their generation will be the one most affected by the rapid transformation of the landscape and ecosystems by humans. This generation will also be responsible for future decisions and has a strong potential for civic involvement [38], for example, with regard to landscaping activities, which can help to steer the human impact on nature in more sustainable directions.

\section{Materials and Methods}

\subsection{Methods}

The presented research is a pilot study that functions as a preparation for extensive qualitative research into the perception of values and problems in typologically diverse territories by various groups of their users. The study is based on the hypothesis that 
the perception of values and problems in the landscape is determined by the age, the level of education and professional experience and that different groups will identify typologically different locations in the landscape. The broadly defined territory of the South Moravian Region, with its high variability of landscape types, was selected as the location for conducting the study. An overview of the methodological procedure is given in Figure 1.

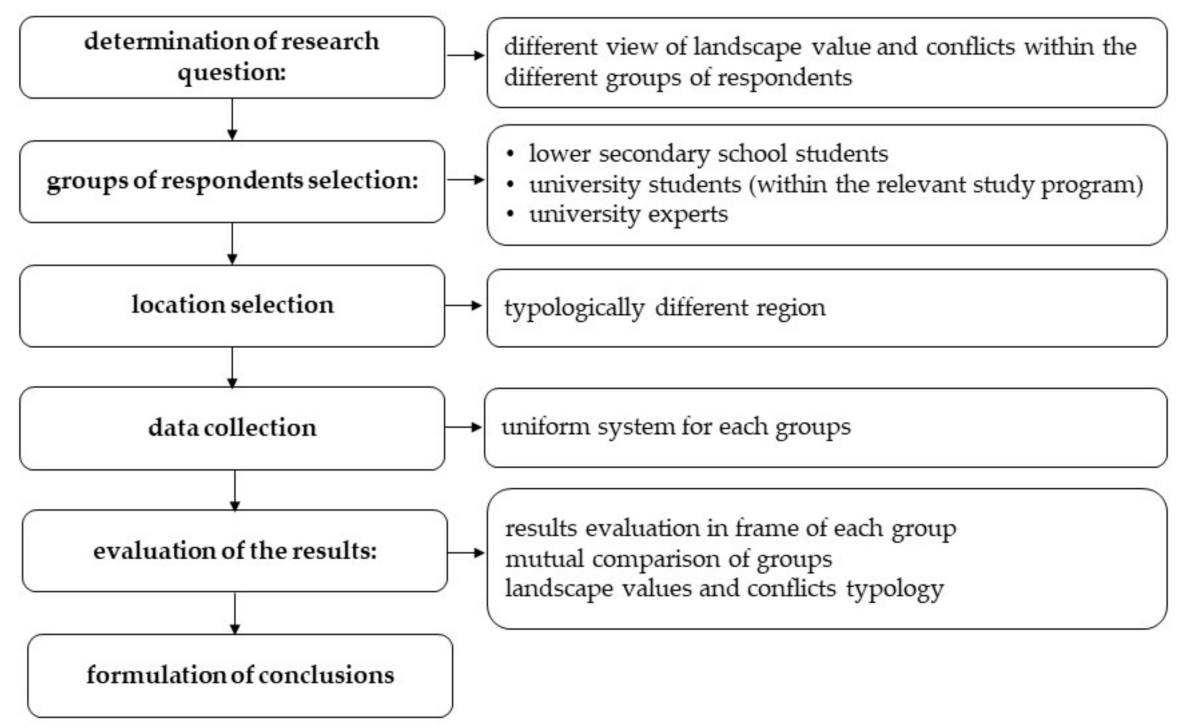

Figure 1. Overview of the methodological approach of the pilot study.

\subsection{Study Area}

The South Moravian Region is an administrative unit of the Czech Republic (a country in Central Europe). The South Moravian Region is situated in the southeast of the Czech Republic, bordering on Austria and Slovakia and five other regions within the Czech Republic. Its area of $7188 \mathrm{~km}^{2}$ covers approximately 9\% of the Czech Republic's territory, thus making the region the fourth largest in the country. The capital of the region is Brno, the nation's 2nd largest city. The population of the South Moravian Region was 1,195,327 at the end of 2020 [39]. The South Moravian Region is divided into 7 districts (see Figure 2a,b).

The share of people living in towns and cities as a percentage of the total population of the region has been steadily decreasing due to suburbanization. There are 673 municipalities in the South Moravian Region, of which 49 have the status of a town or city, with the city of Brno being the largest (population of 382,405 as of 31 December 2020). Five district capitals in the region fall within the category of municipalities with 20-50 thousand inhabitants. By contrast, the 116 smallest municipalities have fewer than 200 inhabitants. Moreover, $32 \%$ of the population of the region live in the region's capital, whereas only $1.3 \%$ live in the smallest municipalities [40].

The natural conditions in the South Moravian Region are diverse and, of course, affect the way of land use in a particular locality. Within the region, four different characters of basic landscape types can be distinguished:

The northern part of the region is a karst landscape with extensive cave complexes, rocky slopes and a number of protected sites.

The southern part of the region is formed by a flat landscape of fields, meadows and vineyards with remnants of floodplain forests along the river. Within this part, the mosaic of the agricultural landscape, and valuable and stable landscape are symptomatic (National Park, Landscape Protected Area, Special Protection Area, UNESCO World Cultural Monument). 
In the eastern part of the region, the landscape gradually rises into the hills. Part of the biosphere reserve is located there.

The last type is the landscape around a large urban agglomeration, the city of Brno. In the north, the forests of the karst landscape are close to it, and in the south, the plains of South Moravia are open.

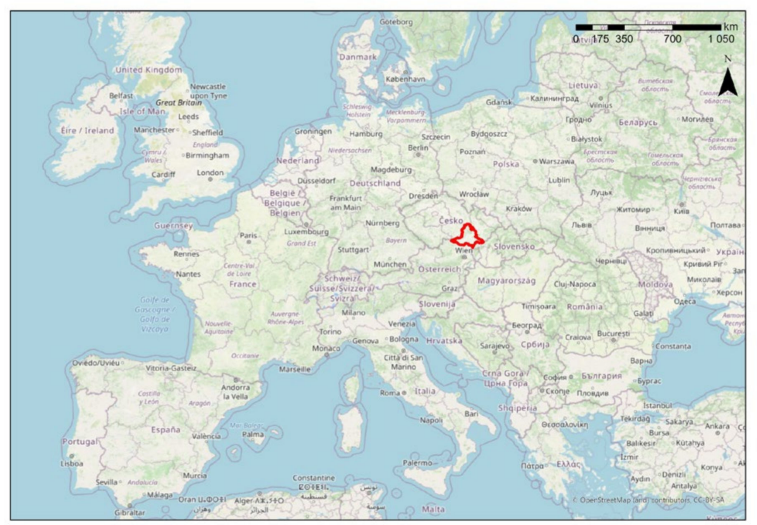

(a) Location within Europe.

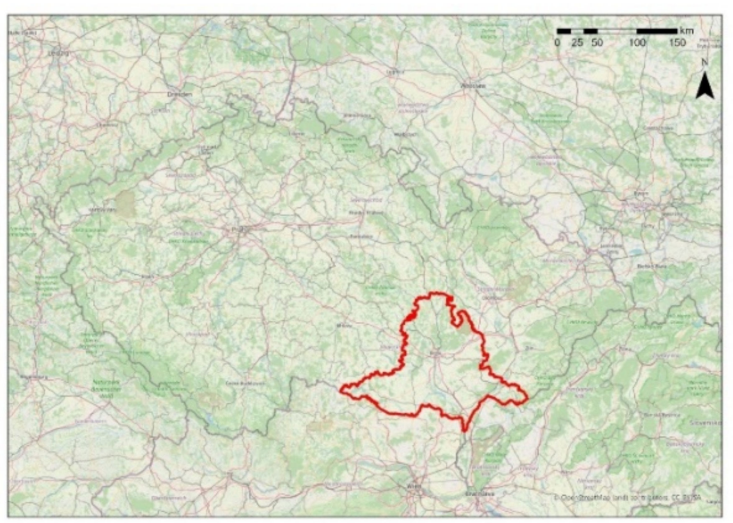

(b) Location within the Czech Republic.

Figure 2. (a,b) Location of the South Moravian region.

\subsection{Data Collection}

The data collection was carried out in the spring of 2020 (between January and May) among students of lower secondary schools (age category: 11-15) and university students (age category: 21-25) of the study program focusing on landscape and spatial planning. For the sake of comparison, an expert evaluation carried out by university lecturers from two universities (Mendel University and Masaryk University) was also performed.

A form for collecting the data was prepared in the ArcGIS Survey123 application, which allows users to collect spatial data (location), visual data (photographs) and context data (any additional data) in the field, using a smart phone. The form created in the ArcGIS Survey123 application is a questionnaire into which the users can upload records of the position of objects or sites and photos of them, in addition to making traditional text and rating entries. The participants were asked to identify the following features in the landscape:

1. High-value locations in built-up areas;

2. High-value locations in an open landscape;

3. Problematic locations in built-up areas that they would like to change;

4. Problematic locations in an open landscape that they would like to change.

For the purpose of locating high-value and problematic locations, the users were advised not to send the data immediately after collecting them in the field but to take their time to think about their text entries. In these entries, the participants were supposed to perform the following:

- Express their reason for selecting the specific location;

- Allocate an attribute to the location (high-value/problematic);

- Justify their assessment;

- Provide more detailed characteristics of the location;

- Propose measures for future management of the area (e.g., the manner of revitalization in the case of problematic locations; or conservation management in the case of highvalue locations).

For an effective collection and visualization of data from several mobile phone users, a map in the ArcGIS Online environment was created in advance to which the response form was connected. In this way the location, visual and context data from all users are 
saved in both the geodatabase (attribute table) and the digital map, the base and content of which can be further edited.

\subsection{Data Analysis}

The text entries were analyzed by means of open coding [41], and the codes for the classification of high-value and problematic locations were chosen in such a way as to integrate specific phenomena in the text into more general concepts (e.g., a building in a dilapidated condition or a neglected building $=$ brownfield). In relation to highvalue locations, it was also analyzed what parts of the landscape are considered highvalue, and the proposals for subsequent conservation were also evaluated. In relation to problematic locations, the reasons why the indicated site was perceived negatively were assessed. In addition to that, the proposed solutions relating to the problematic locations were classified. The findings obtained were generalized on the level of the individually monitored groups. The groups were subsequently compared with each other, with an emphasis on the following:

- The character of the perceived values and the level of their interpretation;

- The sophistication and the nature of the proposals for resolution or conservation.

The study includes selected sample photos of the localities.

\section{Results}

A total of 205 locations were documented by three different user groups-lowersecondary-school pupils, university students and university experts in the data collection system. The data collection was partly anonymous. It is only evident that pupils (or group of pupils) from 17 secondary-school classrooms and students and experts from two universities participated. Their classification according to their type is presented in Table 1.

Table 1. High-value and problematic locations in the model region mapped by different groups.

\begin{tabular}{cccc}
\hline Type of Location & High-Value & Problematic & Total \\
\hline Lower-secondary-school pupils & 42 & 29 & 71 \\
Open landscape & 25 & 8 & 33 \\
Built-up area & 17 & 21 & 38 \\
\hline University students & 30 & 33 & 63 \\
Open landscape & 18 & 18 & 36 \\
Built-up area & 12 & 15 & 27 \\
\hline Experts & 47 & 24 & 71 \\
Open landscape & 41 & 18 & 59 \\
Built-up area & 6 & 6 & 12 \\
\hline Total & $\mathbf{1 1 9}$ & $\mathbf{8 6}$ & $\mathbf{2 0 5}$ \\
\hline
\end{tabular}

Figure 3 illustrates the map output of the data collection; the locations are indicated on the map with colored dots: green dots represent landscape value location and red dots represent landscape conflict location. Text and graphic information can be displayed for each of the registered locations in the drop-down menu in ArcGIS Online environment.

\subsection{Selection of Valuable and Problematic Locations}

Most of the sites ( 84 sites; $41 \%$ ) had the status of a valuable location and were situated in an open landscape. Valuable locations in an open landscape were also the ones with the most elaborate justifications of their selection and the most sophisticated specifications. On the other hand, the proposed solutions were more sophisticated in the case of landscape conflicts.

Tables 2 and 3 and Figure 4 below contain a typology of the valuable and problematic locations. There were typically several reasons for the identification of these locations. In the case of valuable locations, it was most commonly a combination of natural or 
cultural values with recreational potential or nature conservation aspects. Problematic locations were primarily defined by undesirable human activity and subsequent zero maintenance associated with further underdevelopment of the site and reinforcement of its problematic character.

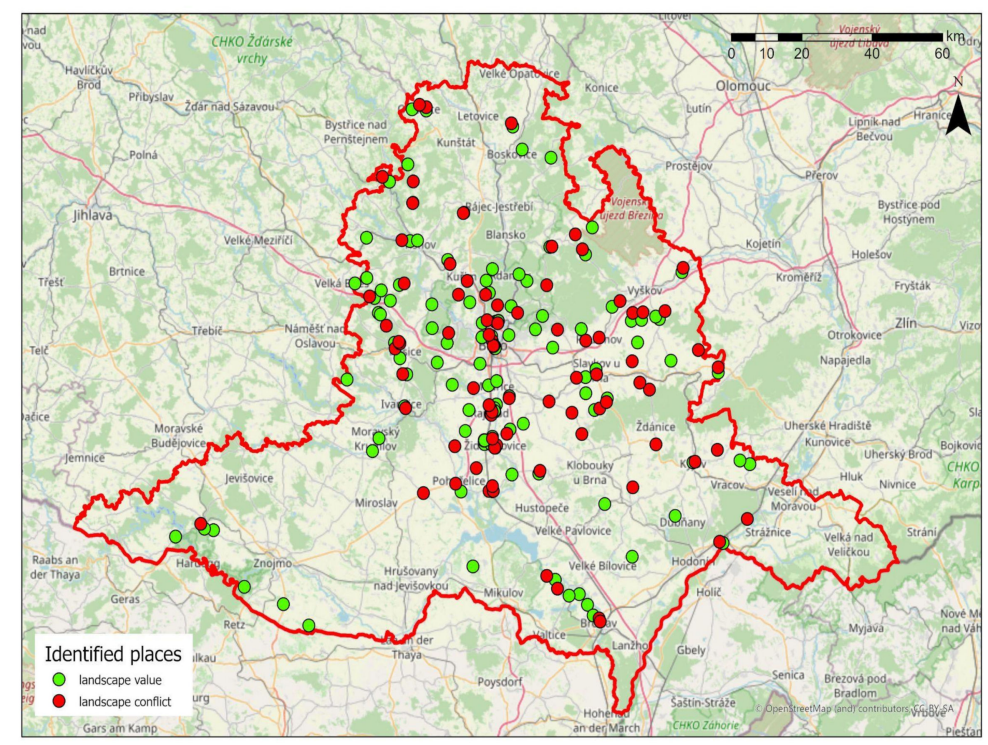

Figure 3. Overview of localities recorded in online data collection system within the South Moravia region.

Table 2. Reason for preference: valuable locations—evaluated by all respondents.

\begin{tabular}{ccc}
\hline Type of Location & Built-Up Area & Open Landscape \\
\hline 1 & Place with a church, monastery or & chapel \\
2 & $\begin{array}{c}\text { Serene place suitable for } \\
\text { relaxation and resting } \\
\text { Place for walks }\end{array}$ & $\begin{array}{c}\text { Place for walks, with preserved } \\
\text { nature }\end{array}$ \\
3 & Place for entertainment and \\
& concerts & $\begin{array}{c}\text { Place for recreation } \\
\text { Presence of protected and } \\
\text { endangered species and trails } \\
\text { (equestrian trails, nature trails and } \\
\text { cycle paths) }\end{array}$ \\
\hline
\end{tabular}

Table 3. Reason for preference: problematic locations—evaluated by all respondents.

\begin{tabular}{ccc}
\hline Type of Location & Built-Up Area & Open Landscape \\
\hline 1 & Dilapidated building & $\begin{array}{c}\text { Dilapidated element in the } \\
\text { landscape }\end{array}$ \\
2 & $\begin{array}{c}\text { Place with problematic and } \\
\text { dangerous people } \\
\text { Place with hygienic problems } \\
\text { (dust, noise) }\end{array}$ & $\begin{array}{c}\text { Dusty and noisy place (often a } \\
\text { quarry) }\end{array}$ \\
3 & Polluted place & $\begin{array}{c}\text { Disturbance of landscape character } \\
\text { Absence of vegetation elements, } \\
\text { dangerous erosion }\end{array}$ \\
\hline
\end{tabular}




\section{Frequency of responses to questions}

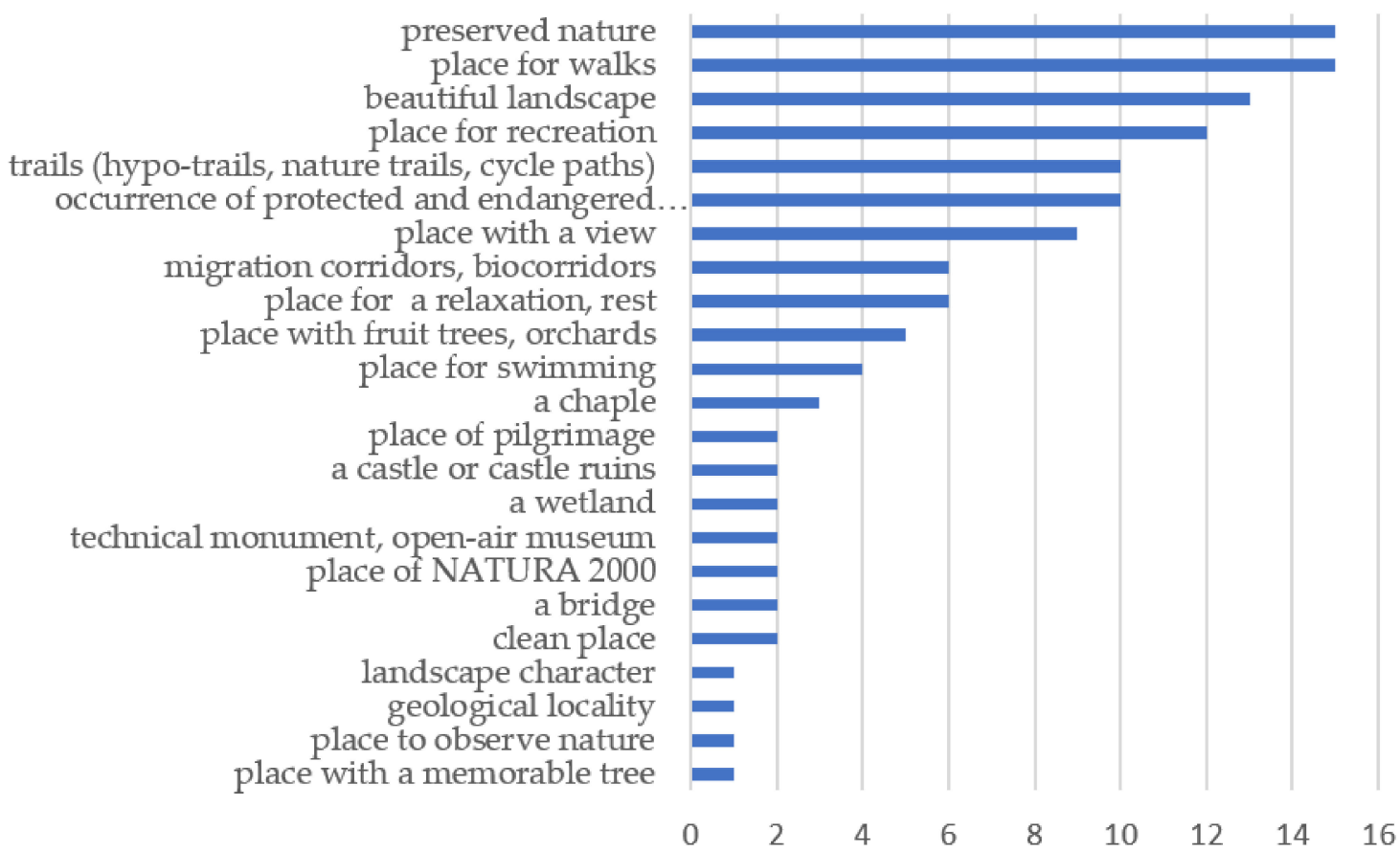

Figure 4. Most preferred valuable areas in the open country listed by all respondents.

\subsection{Lower-Secondary-School Students (Age Category 11-15)}

Lower-secondary-school students mapped 71 sites (42 valuable locations and 29 problematic locations). The pupils mapped all the sites in the territory of the municipality where they live or study.

Valuable locations:

In regard to "built-up areas", they preferred places associated with cultural monuments that could be used for relaxation, walks and entertainment (concert venues, outdoor theaters, summer cinemas, parks, sports grounds, historic town centers and museums). In "open landscape", they primarily identified as valuable locations places with preserved nature and aesthetic landscapes and places suitable for walking, recreation and hiking (cycle paths, walking trails, equestrian trails, hiking trails). Other preferences-usually less frequent-included: technical monuments, chapels, bridges, castles and ruins.

Here is an example of a respondent's statement (illustrated by Figure 5a,b):

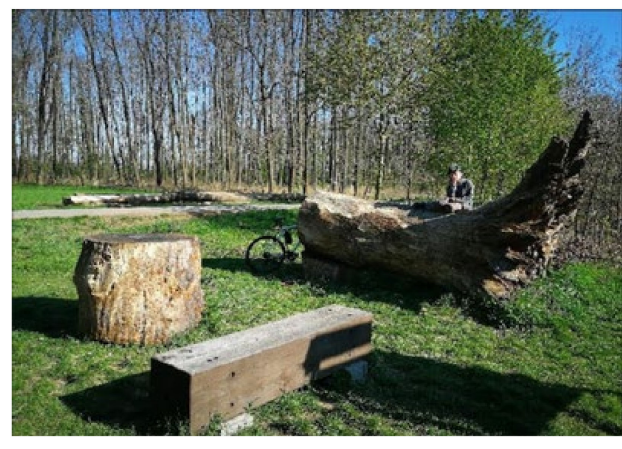

(a) the overall context of the location.

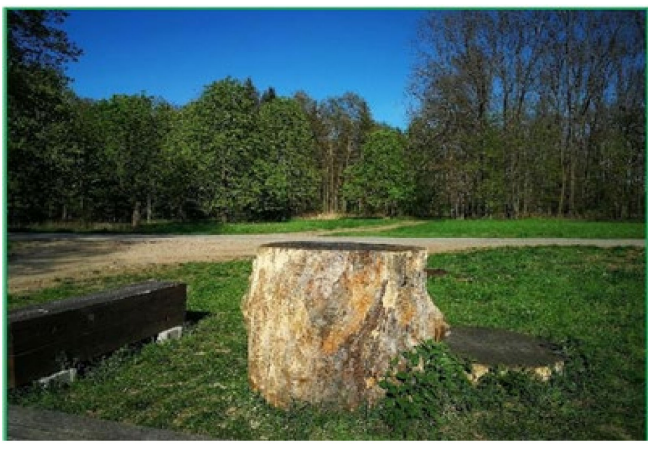

(b) ) locality in the detail.

Figure 5. (a,b) Resting place on the Židlochovice-Velké Němčice cycle path (valuable place—open landscape). 
"We chose this place because it is a wonderful place to relax, for example after a long bike ride. We like that there is no garbage lying there" (lower-secondary-school pupil).

Problematic locations:

In "built-up areas", lower-secondary-school students reported mainly dilapidated buildings, places with problematic (homeless) people and places contaminated with dust or noise. In "open landscape", problems similar to those in built-up areas were reported. However, there were also places such as illegal dumps, places with water pollution due to the absence of sewerage and busy junctions.

Here is an example of a respondent's statement (illustrated by Figure 6a,b):

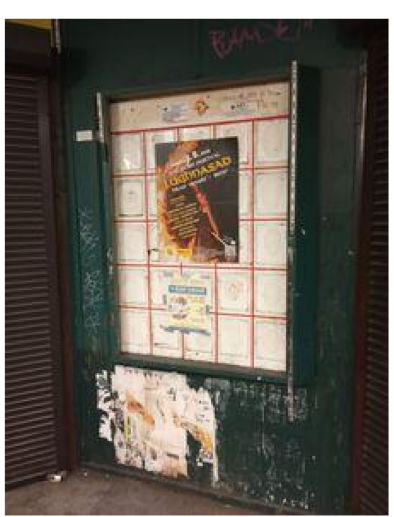

(a) locality in the detail.

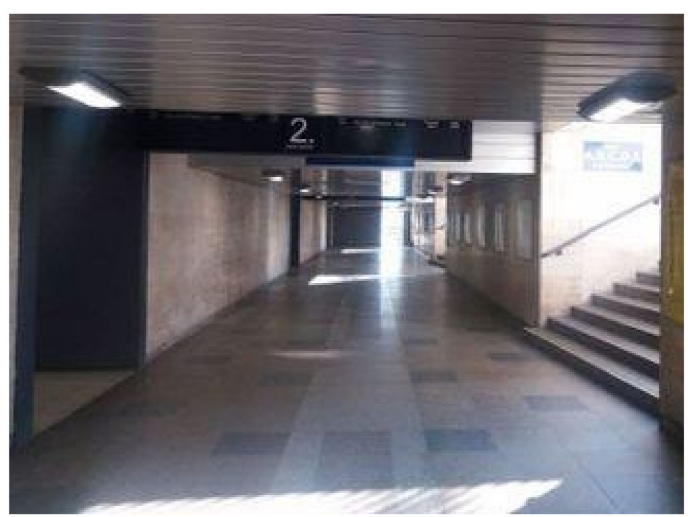

(b) the overall context of the location.

Figure 6. $(\mathbf{a}, \mathbf{b})$ Underground corridor in the Brno city center close to the main train station (problematic location-built-up area).

"I chose the place because it is dangerous, in my opinion, and I do not feel safe in this environment. There are problematic groups of people, it smells there and it is polluted there" (lower-secondary-school pupil).

\subsection{University Students (Age Category 21-25)}

University students mapped 63 sites (30 valuable locations and 33 problematic locations in urban and open landscape). The university students usually mapped the sites in the territory of the municipality where they live because they know this locality well. In contrast to the lower secondary pupils, not all university students live in the model region. Moreover, they are not limited in their movement across the region (financially and in terms of accompaniment). Therefore, in several cases, they mapped more distant localities they found interesting or wanted to visit. The same approach was evident by experts.

Valuable locations:

In "built-up areas", they preferred places associated with cultural monuments that could be used for relaxation, walks and entertainment (concert venues, outdoor theaters, summer cinemas, parks, sports grounds, historic town centers and museums). In "open landscape", they primarily identified as valuable locations places with preserved nature and aesthetic landscapes (illustrated by Figure 7) and places suitable for walking, recreation and hiking (cycle paths, walking trails, equestrian trails, hiking trails). Other preferencesusually less frequent-included technical monuments, chapels, bridges, castles and ruins.

Problematic locations:

When identifying problematic locations in "built-up areas", university students mainly selected dilapidated buildings, including industrial or agricultural brownfields. The most frequently identified problematic locations in an "open landscape" were places threatened by water erosion and large patches of arable land without spinneys, bio-corridors or grass strips. 


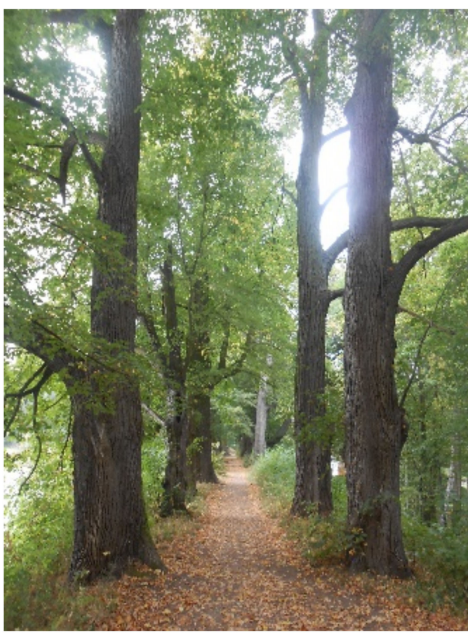

(a) historical tree line.

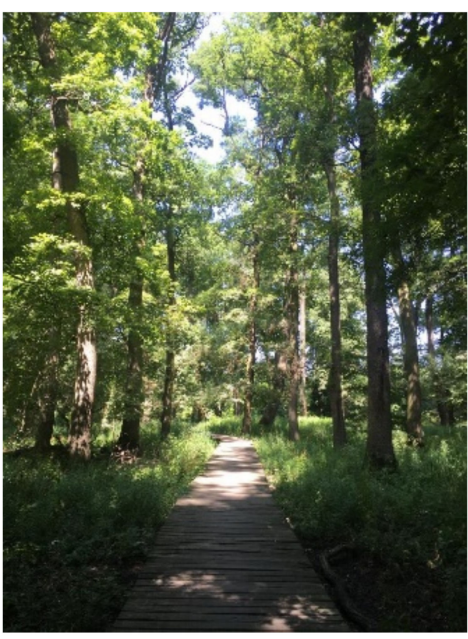

(b) nature trails in floodplain forest.

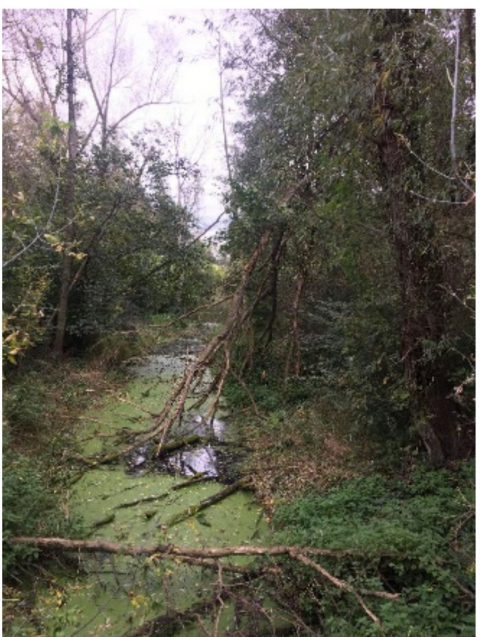

(c) the rest of the floodplain.

Figure 7. (a-c) Alleys in South Moravian region (valuable location-open landscape), university student.

Here is an example of a respondent's statement (illustrated by Figure 8a,b):

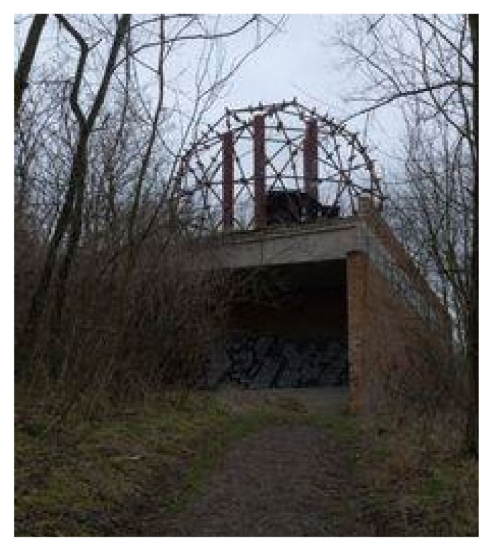

(a) locality in the detail.

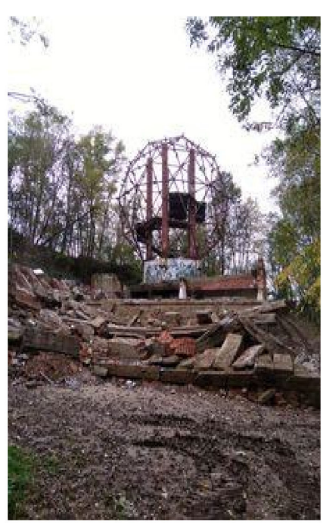

(b) the overall context of the location.

Figure 8. (a,b) Unfinished monument (Křepice)—dilapidated structure (valuable location—open landscape), university student.

"I chose this place because it is an unfinished monument with a unique lookout tower that has been deteriorating since the revolution in 1989 and the cost of its completion or repair was too great a burden for the municipality" (a university student).

\subsection{Experts}

A total of 71 sites were assessed (47 valuable locations and 24 problematic locations). Valuable locations:

For an "open landscape", this group primarily selected places valuable due to the presence of natural and near-natural ecosystems. Often, these were locations identified within larger legally protected sites and also locations that enhance the ecological stability of the landscape (bio-corridors and interaction elements). Another reason for including particular locations among the valuable ones was the cultural and historical value of the place, e.g., chapels on hills overlooking the landscape, old bridges or ponds. In built-up areas, the group identified places with historical and cultural monuments (churches, castles, bridges or windmills) as those of the greatest value.

Problematic locations: 
For "open landscape", sites with degraded ecosystems (e.g., due to opencast mining), sites with disrupted landscape character (in connection with a radio/TV tower or a photovoltaic power plant on arable land) and sites where there is a conflict of interest between nature protection and other types of land use were identified as problematic locations. Other reasons for classifying a particular location as problematic included the presence of invasive species or contaminated soil.

As far as "built-up areas" are concerned, locations with unsightly dilapidated buildings and agricultural brownfields and areas with greenfield construction have been primarily identified as problematic.

\subsection{Proposals for Taking Care of Valuable Locations and Proposed Solutions for Problematic Locations}

For all the evaluated sites, after their location, specification and justification of the selection, their further management (management plan) was proposed. For valuable locations, further management with the goal of preserving their value was suggested, while for problematic locations, improvement measures and the future target form of the location were proposed. As there were no differences between the management proposals for built-up locations and the management proposals for open landscape locations, they are evaluated here collectively within the given category (valuable locations/problematic locations).

A total of 198 management plans were proposed for 117 valuable locations-there were multiple proposals for further management of certain sites. The most frequently submitted proposals are listed in Table 4 . The most important thing, according to all groups of respondents, is to preserve the valuable locations in their current state and prevent their degradation. Pupils opted for simple management based on measures such as regular cleaning of the site or installation of litter bins. For locations associated with a particular building (such as a church or a chapel), they usually suggested reconstruction of the dilapidated parts and regular inspection of the condition of the building or ensuring the maintenance of their current state by installing a camera system. This group of respondents generally did not propose complex measures and preferred preservation of the status quo. Their proposals were limited to simple drawings; the focus was on a verbal description. The proposals of university students focused mainly on green space maintenance in both types of landscape, but with a more pronounced emphasis on the establishment, maintenance and restoration of green spaces in urban environments. The results show that university students are already able to evaluate the basic requirements for the maintenance of specific sites and are looking for other ways to improve their conditions (e.g., replanting of avenues according to the historical state of the landscape, revitalization of existing avenues by replacing unhealthy trees, mosaic mowing of meadow vegetation, introduction of stabilizing landscape elements and strengthening of anti-erosion protection). This group worked with maps and other graphic materials, in which they schematically plotted their proposals and the target state of the landscape. The experts based their proposals on a more detailed analytical-synthetic evaluation of the landscape-ecological characteristics. The graphic and conceptual level of their management proposals was not evaluated and compared with the other categories; it served only as a comparative basis for defining the typology of proposals.

Here are some of the respondents' statements:

An open landscape: "We must continue to take care of the site as we have been doing so far, keeping it tidy and not littering. It is also necessary not to destroy anything here, and to take proper care of the nature around it so that it remains as beautiful as it is now" (lower-secondary-school pupil).

Built-up area: "The church is in a very nice condition and the surrounding area as well, so I see no reason to suggest any improvements. Perhaps in the future, it would be a good idea to modify the front garden and restore some of the adjacent greenery" (university student). 
There were 100 suggested solutions for 86 problematic locations. Proposals by the individual groups of respondents did not differ significantly in terms of their types. The most frequently submitted proposals are listed in Table 5. The most common suggestions were to reconstruct/revitalize the building or site, put it to an alternative use or demolish the building. These proposals concern typically dilapidated buildings, which, in the view of the evaluators, are the most problematic objects both in built-up areas and in an open landscape. For variously polluted or unaesthetic sites, planting and maintenance of greenery have usually been proposed as a solution. Quite often, care is also required for corridors that serve as the main road arteries for both transport and active recreation in the form of cycling, walking or inline skating.

Table 4. Proposal for the management of valuable locations (in both built-up areas and open landscape)—all respondents.

\begin{tabular}{cc}
\hline Proposal for the Management of the Valuable Location & Number \\
\hline Preservation of existing greenery & 67 \\
Conserving the location by simple measures (not polluting & 56 \\
or destroying it) & 37 \\
Planting/restoration of greenery & 28 \\
Preservation of the site/facility/building & 10 \\
Installation of a camera system & \\
\hline
\end{tabular}

Table 5. Proposed solutions for problematic locations (in both built-up areas and open landscape)all respondents.

\begin{tabular}{cc}
\hline Proposal for the Management of the Valuable Location & Number \\
\hline $\begin{array}{c}\text { Reconstruction/revitalization of the building/the whole site } \\
\text { Planting of greenery + greenery maintenance (incl. weeding } \\
\text { out of wind-dispersed plants) }\end{array}$ & 35 \\
$\begin{array}{c}\text { Demolition of the building and proposal for alternative } \\
\text { Road repair + road maintenance, noise and dust reduction, } \\
\text { aesthetic integration of the road into the landscape }\end{array}$ & 25 \\
\hline
\end{tabular}

Typologically, the solutions proposed by all of the groups involved were comparable (for sites of a similar kind), but the ways of expressing them differed in the same way as in the previous category (valuable locations).

Here are some of the respondents' statements and proposals for dealing with the problematic areas (illustrated by Figures $9 a-f$ and 10a,b):

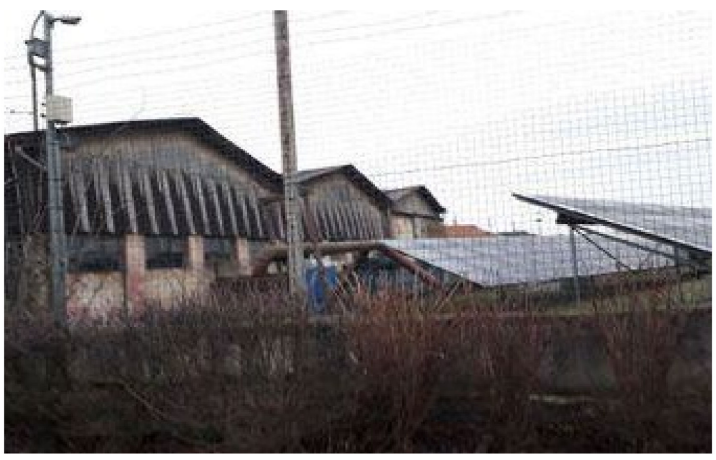

(a) brownfield (unused factory).

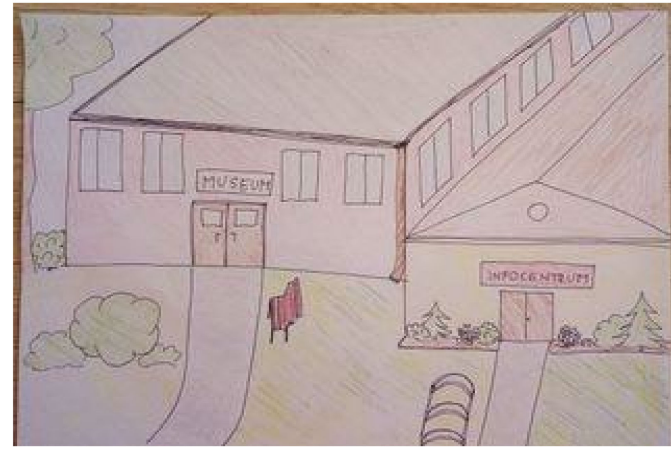

(b) new use proposal of locality.

Figure 9. Cont. 


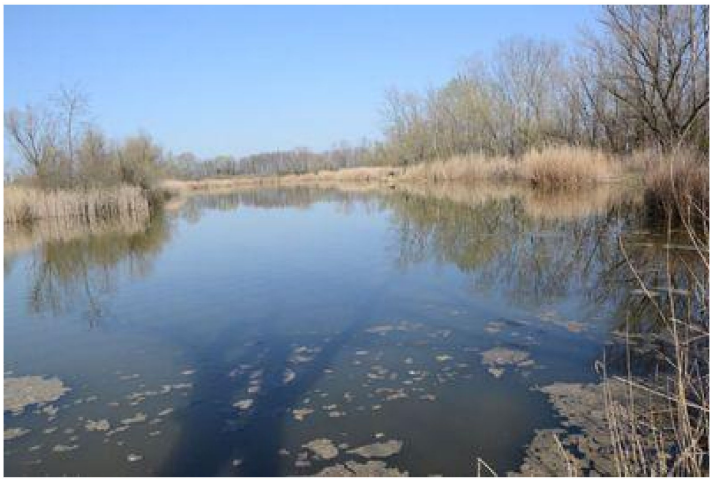

(c) pond with mature riparian vegetation.

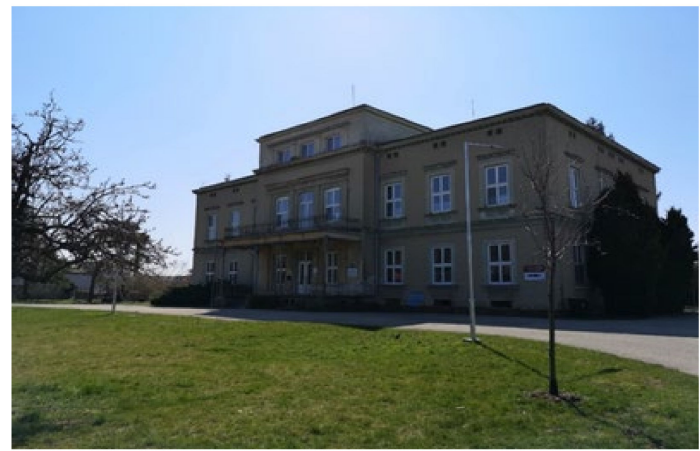

(e) unused public building.

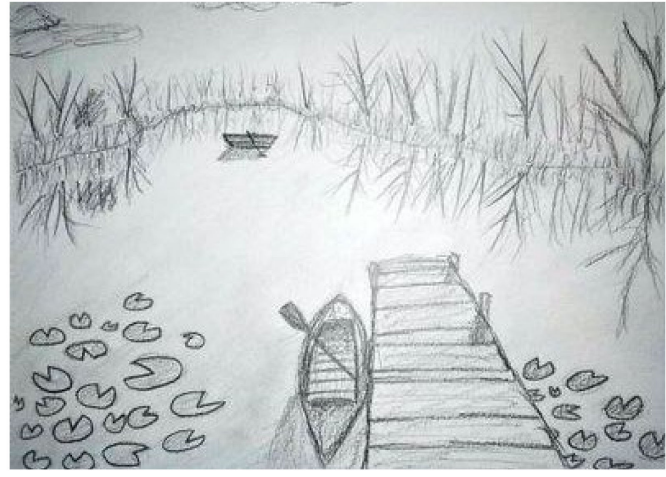

(d) recreational use design.

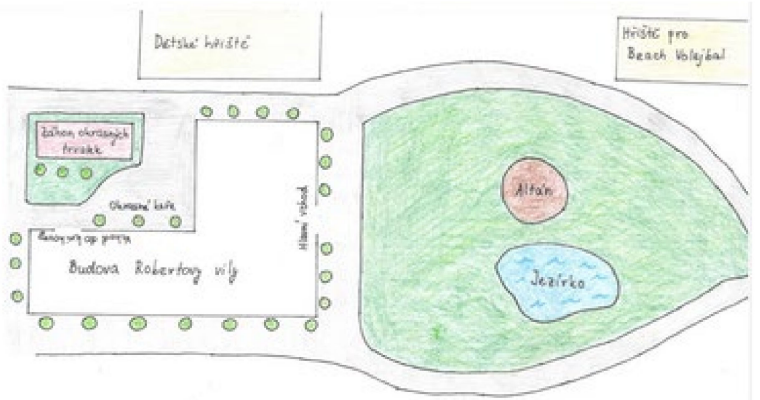

(f) new use proposal of public building.

Figure 9. (a-f) Example of submitted proposals for dealing with the problematic areas. Source: photographed and elaborated by pupils of the participating school (a grammar school in Židlochovice).

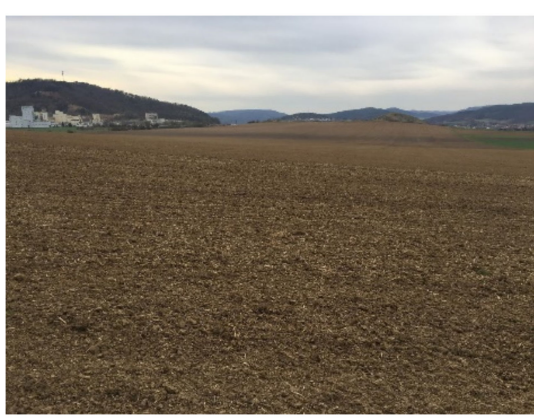

(a) large area of arable land without green infrastructure.

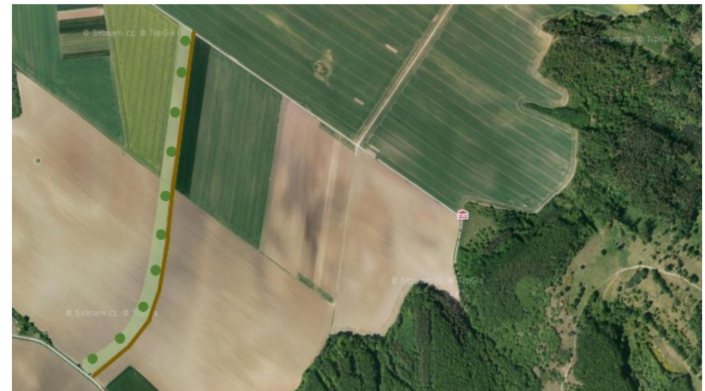

(b) proposal of a new land arrangement using green infrastructure.

Figure 10. (a,b) Example of submitted proposals for dealing with the problematic areas. Source: photographed and elaborated by pupils of the participating school (a grammar school in Židlochovice).

Built-up area: "Demolish the whole building because it is in a very bad shape. In its place, a playground and an educational area that could be used by a kindergarten/school could be built" (lower-secondary-school pupil).

Open landscape: "Personally, I would suggest planting trees and shrubs along the fields to prevent wind erosion. At the same time, a greater number of mature trees could block traffic noise, which is also a problem for the village. As far as water erosion is concerned, the most threatened area is in the vicinity of the Bošovicky and Otnický brooks, where I would suggest drainage" (university student). 


\subsection{Typology of Landscape Values and Conflicts-Generalization of Results}

The qualitative analysis of the obtained records allows for the generalization of the values and conflicts in the landscape identified by the different groups. It can be concluded that, in terms of the typology of the valuable and problematic locations, the individual groups of respondents did not differ significantly, and the selection of location types was similar across all groups. Within each group, however, the following specificities in the identification and description of the locations can be distinguished.

Lower-secondary-school students identified cultural values associated with leisure opportunities, and the descriptions contained emotional overtones and indicated a personal connection to the locality. The locations were usually places connected with everyday life (going to school and the neighborhood where they lived) and the opportunity to spend time together with others. The locations had a direct link to some of the levels of the road network (footpaths, dirt roads and traffic roads). In general, cultural values and an anthropocentric approach to the use of the locations predominated in this group.

University students preferred natural values associated with formal values based on general consensus (legally protected parts of nature, green spaces in any form) or conflicts associated with society-wide impacts (e.g., soil erosion). Compared to secondary-school students, a more even distribution of the locations within the given cadastral area is evident, and the existence of a link of the location to the road network is not prevalent. Natural values dominate, the social dimension of the landscape (the possibility of meeting) is lacking, but the proposed solutions are directed more towards solving the symptoms, and not the cause of the situation.

The experts based their conclusions on a deeper analysis of the area, and it is evident that the proposals are based on a complex solution with an overlap into the surrounding landscape. The identification of specific micro-locations within broadly defined areas (e.g., nature reserves) with a definition of value at a local scale is essential. As regards landscape conflicts, the most frequently pointed out threats are the quantitative (non-conceptual design of the area and land take) and qualitative (contamination and soil erosion) threats to the land. Problem-solving and value management in the medium- and long-term dominate.

\section{Discussion}

The findings of our research supplemented the findings of previous studies [36,37], suggesting that children and adolescents perceive their environment differently from the adult generation. Conceptualizing individual groups' views with the emphasis on pupils' environmental perception of the landscape gave us a more comprehensive understanding of the space they live in. It shows how different groups perceive, cognize, reflect or adapt to the physical fundamentals of their surroundings [42]. It should be added, however, that the findings of our research more broadly confirmed the existence of common features in landscape perception across the groups.

A major difference between the groups is the emotional approach to defining valuable and problematic locations (e.g., fear of the unknown or danger, a positive experience during a trip, etc.), which is typical of the youngest group of respondents. The other groups did not apply this approach, which should ideally be combined with an expert approach. Another difference is the social dimension of the identified locations-again symptomatic of the youngest group. Sharing their experiences with others is very important to them and they have identified places where they can spend time together with their family or friends. Good accessibility of the place (connection to a road) was also important to them and they tended to choose locations that they were familiar with, in line with their emotional focus. Similar conclusions were reached by Travlou and Owens [37], who conducted interviews on landscape preferences with 25 adolescents aged 14-18 in California. His findings confirmed significant differences in the preferences of adolescents compared to adults. Teenagers most appreciated places in nature where they could be with their friends and which they could regard as "their own" (i.e., places that were familiar to them). This conclusion was also confirmed by the findings of Abbott-Chapman and 
Robertson [35]. These authors conducted quantitative research with young people aged 14-19 in Australia and concluded that younger children preferred the (familiar) city center, the neighborhood of their homes and the homes of their friends. The older ones, on the other hand, preferred more secluded places in the countryside that provided privacy. Our research clearly confirms this conclusion. Further research on this topic has been published by Mäkinen and Tyrväinen [34]. The research focused on the use of green spaces by the young generation. In their study, they assessed the attitudes of 300 adolescents aged 14-19 living in Helsinki and found that these groups highly valued green spaces. However, they emphasized these "green places" mainly as places to meet friends.

The residents' perspective may be influenced by their perception of the so-called everyday landscape. Lee [43] confirmed through his research that residents are "relatively insensitive to the visual and physical characteristics of landscape objects, while sensitive to the "relationship" with the landscapes formed through the residents' experiences". This fact is very significant in landscape planning and should always be taken into account. However, our research shows that this subjective approach to landscape is being replaced by an objective approach and the intensity of the objectification is directly proportional to the level of expertise.

Nevertheless, in terms of the perceived values and problems in the landscape, it is clear that all the respondent groups involved identified typologically identical locations. Differences could only be found in the way of their interpretation. University students are better able to articulate the values and problems connected with the land due to the relevant knowledge acquired through their studies. Younger pupils most commonly identified "dilapidated industrial buildings" as one of the problematic locations, while university students usually called this problem "brownfields" and were able to identify complementary environmental burdens and the need for remediation. Due to their studies, university students are also able to define problems that are not visible at first sight in the landscape (e.g., unstable landscape structure indicating a potential negative impact-a concrete example would be large blocks of arable land without stabilizing greenery which indicate an increased risk of erosion that the younger students are not aware of). As with the description of the choice of the locations, there is a noticeable difference between the articulation of the proposals by primary- and secondary-school students and by university students who know the relevant technical terminology. While primary- and secondaryschool students use age-appropriate "colloquial language" in the formulation of their proposals, university students often bolster their proposals by using technical terms and various documents, such as development strategies, conservation plans, etc. However, the view of the younger generation is typologically quite consistent with that of the experts.

Our study has also shown that the respondents have a positive relationship with landscape greenery both in an open landscape and especially in urbanized environments. The qualitative condition of the greenery was an absolutely crucial factor in the evaluationwhether or not the greenery was maintained was often an indicator of whether a location was seen as valuable or problematic. The greenery in the landscape is a place for relaxation, recreation and walks; it is a place to meet friends. This is also confirmed by the global concept of landscape greenery (small landscape features, avenues and tree plantations), the importance of which is mainly associated with an urban environment. The correlation between the social preferences of the inhabitants and the location of these elements is thus a crucial aspect of planning. There are numerous studies that describe precisely the strong preference of residents for spaces with planted trees and alleys in urban environments [44-47].

Both categories (pupils and university students) identified as valuable locations also places other than those with preserved nature-often, sites associated with cultural and historical values prevailed. The preference for cultural values or values based on human activity in the landscape has also been confirmed by Ruskule et al. [48], among others.

Understanding the perspective of young people is particularly relevant with regard to the fact that their generation will be the one most affected by the rapid transformation of 
the landscape and ecosystems by humans. Moreover, this generation will be in charge of future decision-making and has a strong potential for civic engagement [38], for example, in terms of landscaping activities that can help manage human impact on nature in more sustainable ways. If we teach the current young generation to understand the relationships in the landscape system, the future generation can benefit. It is evident (at least in Central Europe) that chaotic spatial planning does not work without simultaneously creating a link between society and (their) landscape and without understanding cause-effect in land use. We can learn from the past.

\section{Conclusions}

Understanding the level of perception of the landscape by young people is very important for landscape planning. It will always be the younger generation that will be most affected by the rapid transformation of the landscape, due to current decisions. The present generation is in charge of land-use decision-making, which determines trends in the development and condition of the landscape over the long-term and should conduct the landscape planning in the spirit of sustainable development and conservation of values. It is, therefore, necessary to understand the attitudes of the members of the current young generation, as well as their interpretation of values and problems.

From the results of the research presented so far, the following general conclusions can be drawn regarding the perception of values and conflicts in the landscape:

The presumption of the study was partly confirmed-we conclude the correlation between age, education and experience to the perception of landscape value and conflictsbut not at the level of typology. The younger generation (both younger groups of respondents) can perceive and formulate values and problems in the landscape, and their perspective is quite comparable to expert evaluation. The level of location specification and the sophistication of the management plans correspond to the given age and education. The differences in the conception and sophistication of the proposed solutions were as expected, and they were directly proportional to the education received. An interesting conclusion, however, is the fact that all the groups involved defined typologically identical values and problems, possibly with only minor specific differences. With the youngest respondents, cultural values predominated. Lower-secondary-school students associate landscape values mainly with personal experience and perceive the landscape as a space for spending leisure time together. This seems to be the optimal attitude in terms of spatial planning, as it can promote a comprehensive approach to land use and collective responsibility for preserving values and solving problems. The research has confirmed the high emotional stimulation that places in the landscape evoke in children. Thus, the presumption that the younger students would identify only obvious values and conflicts was not confirmed. The potential of emotional connections should be used in professional landscape assessments in order to make it possible to take into account values and conflicts that are not commonly observable. University students preferred values related to nature and problems affecting the stability of the landscape. However, compared to the experts, the values and problems perceived by them were more general, and in the case of problems, the solutions suggested addressed rather the manifestations than the causes of the issues. It is likely that finding causal links and linkages in a landscape system is influenced by practice and experience.

Several suggestions for further research emerged from the pilot study. More valuable locations than problematic locations were entered into the data collection system, with a predominance of valuable locations in an open landscape. It can be assumed thatfrom the point of view of human perception-it is more natural to identify valuable parts of the landscape connected with less affected areas outside built-up spaces. University students were an exception, as they identified an equal number of locations of each category (generally one problematic location and one valuable location for a particular cadastral area). It can be assumed that the teaching of relevant subjects leads students to think critically and look for balance in the landscape system. 
At the same time, the proposals for management of the problematic locations are more sophisticated than the proposals for management of the valuable locations. This applies across all groups. It can be assumed that people are more likely to perceive the need for a solution to a problem and that they see this as more important than the sustainable management of values, as it is something that they often take for granted and subsequently fail to realize its necessity. It is evident that the preservation of valuable areas is not yet fully appreciated. It will be interesting to focus future research on this particular disproportion, which provides the potential for future planning practice.

Simultaneously, cooperation with the Local Government is required. Without Local Government support, participative mapping and using its findings would not work in practice. In this study, we have established cooperation with several municipalities (Local Government). Our common intent is to design the virtual education trails based on the valuable and problematic localities. Within these places, an augmented reality based on the management proposal will be built. These trails will be drawing attention to possible risks of land use (territorial conflicts) in a specific landscape context.

Author Contributions: Conceptualization, H.V. and H.S.; methodology, H.V. and H.S.; software (data collection), P.P.; validation, P.F.; formal analysis, P.F. and H.S.; data collection, J.O., H.S., P.F. and H.V.; resources, H.V.; data curation, P.F. and H.S.; writing-original draft preparation, H.V.; writingreview and editing, H.S.; visualization, P.P.; supervision, H.S.; project administration, H.V.; funding acquisition, H.V. All authors have read and agreed to the published version of the manuscript.

Funding: This research was funded by the Technology Agency of the Czech Republic, grant number TL02000076.

Institutional Review Board Statement: Not applicable.

Informed Consent Statement: Not applicable.

Data Availability Statement: Not applicable.

Conflicts of Interest: The authors declare no conflict of interest.

\section{References}

1. UN Environment (Ed.) Global Environment Outlook-GEO-6: Healthy Planet, Healthy People; Cambridge University Press: Cambridge, UK, 2019. [CrossRef]

2. Ferretti, V.; Grosso, R. Designing successful urban regeneration strategies through a behavioral decision aiding approach. Cities 2019, 95, 102386. [CrossRef]

3. Mitchell, B. Participatory partnerships: Engaging and empowering to enhance environmental management and quality of life? In Quality-of-Life Research in Chinese, Western and Global Contexts; Shek, D.T., Chan, Y.K., Lee, P.S., Eds.; Springer: Dodrecht, The Netherlands, 2005; pp. 123-144. ISBN 978-1-4020-3601-9. [CrossRef]

4. Poskitt, S.; Waylen, K.A.; Ainslie, A. Applying pedagogical theories to understand learning in participatory scenario planning. Futures 2021, 128, 1-18. [CrossRef]

5. Garcia, X.; Benages-Albert, M.; Valll-Casas, P. Landscape conflict assessment based on a mixed methods analysis of qualitative PPGIS data. Ecosyst. Serv. 2018, 32, 112-124. [CrossRef]

6. Ernoul, L.; Wardell-Johnson, A.; Willm, L.; Béchet, A.; Boutron, O.; Mathevet, R.; Arnassant, S.; Sandoz, A. Participatory mapping: Exploring landscape values associated with an iconic species. Appl. Geogr. 2018, 95, 71-78. [CrossRef]

7. Gonzalez-Urango, H.; Le Pira, M.; Inturri, G.; Ignaccolo, M.; García-Melón, M. Designing walkable streets in congested touristic cities: The case of Cartagena de Indias, Colombia. Transp. Res. Procedia 2020, 45, 309-316. [CrossRef]

8. Nadin, V.; Stead, D.; Fernandez-Maldonado, A.; Dabrowski, M. Integrated, adaptive and participatory spatial planning: Trends across Europe Integrated, adaptive and participatory spatial planning: Trends across Europe. Reg. Stud. 2020, 55, 791-803. [CrossRef]

9. Brown, G.; Fagerholm, N. Empirical PPGIS/PGIS mapping of ecosystem services: A review and evaluation. Ecosyst. Serv. 2015, 13, 119-133. [CrossRef]

10. Brown, G.; Weber, D. Measuring change in place values usingpublic participation GIS (PPGIS). Appl Geogr. 2012, 34, 316-324. [CrossRef]

11. Garcia-Martin, M.; Fagerholm, N.; Bieling, C.; Gounaridis, D.; Kizos, T.; Printsmann, A.; Müller, M.; Lieskovský, J.; Plieninger, T. Participatory mapping of landscape values in a Pan-European perspective. Landsc. Ecol. 2017, 32, 2133-2150. [CrossRef]

12. Huck, J.J.; Whyatt, J.D.; Coulton, P. Spraycan. A PPGIS for capturing imprecise notions of place. Appl. Geogr. 2014, 55, 229-237. [CrossRef] 
13. Št'astná, M.; Vaishar, A. Values of rural landscape: The case study Chlum u Třeboně (Bohemia). Land Use Policy 2020, $97,104699$. [CrossRef]

14. Biedenweg, K.; Williams, K.; Cerveny, L.; Styers, D. Is recreation a landscape value?: Exploring underlying values in landscape values mapping. Landsc. Urban Plan. 2019, 185, 24-27. [CrossRef]

15. Dupont, L.; Antrop, M.; van Eetvelde, V. Does landscape related expertise influence the visual perception of landscape photographs? Implications for participatory landscape planning and management. Landsc. Urban Plan 2015, 141, 68-77. [CrossRef]

16. Eiter, S.; Lange Vik, M. Public participation in landscape planning: Effective methods for implementing the European Landscape Convention in Norway. Land Use Policy 2015, 44, 44-53. [CrossRef]

17. Spencer, S. The eHow: Facts about Teenage Pregnancy. 2011. Available online: http://www.ehow.com/about_4619346_teen (accessed on 6 June 2021).

18. Clemetsen, M.; Krogh, E.; Thorén, K.H. Landscape perception through participation: Developing new tools for landscape analysis in local planning processes in Norway. In The European Landscape Convention: Challenges of Participation; Jones, M., Stenseke, M., Eds.; Springer: Dodrecht, The Netherlands, 2011; Volume 13, pp. 219-238. ISBN 978-90-481-9931-0. [CrossRef]

19. Larsson, A.; Peterson, A.; Bjärnborg, E.; Haaland, C.; Gyllin, M. Regional landscape strategies and public participation: Towards implementing the European Landscape Convention in Sweden. In The European Landscape Convention: Challenges of Participation; Jones, M., Stenseke, M., Eds.; Springer: Dodrecht, The Netherlands, 2011; Volume 13, pp. 261-274. ISBN 978-90-481-9931-0. [CrossRef]

20. Michelin, Y.; Joliveau, T.; Planchat-Héry, C. Landscape in participatory processes: Tools for stimulating debate on landscape issues. In The European Landscape Convention: Challenges of Participation; Jones, M., Stenseke, M., Eds.; Springer: Dodrecht, The Netherlands, 2011; Volume 13, pp. 145-173. ISBN 978-90-481-9931-0. [CrossRef]

21. Ramos, I.L. Landscape Quality Objectives' for remote rural landscapes in Portugal: Addressing experts' and stakeholders perspectives on future developments. In The European Landscape Convention: Challenges of Participation; Jones, M., Stenseke, M., Eds.; Springer: Dodrecht, The Netherlands, 2011; Volume 13, pp. 199-218. ISBN 978-90-481-9931-0. [CrossRef]

22. Jones, M.; Stenseke, M. (Eds.) The European Landscape Convention: Challenges of Participation; Landscape Series; Springer: Dodrecht, The Netherlands, 2011; Volume 13, pp. 27-44.

23. Pánek, J. From mental maps to geoparticipation. Cartogr. J. 2016, 53, 300-307. [CrossRef]

24. Pánek, J. Mapping citizens emotions: Participatory planning support system in Olomouc, Czech Republic. J. Maps 2019, 15, 8-12. [CrossRef]

25. Trojan, J.; Schade, S.; Lemmens, R.; Frantál, B. Citizen science as a new approach in Geography and beyond: Review and reflections. Morav. Geogr. Rep. 2019, 72, 254-264. [CrossRef]

26. Lee, K.A.; Lee, R.L.; Bell, P. A review of Citizen Science within the Earth Sciences: Potential benefits and obstacles. Proc. Geol. Assoc. 2020, 131, 605-617. [CrossRef]

27. Yusoff, S.M.; Yusoff, F.; Arshad, F.A. Effectiveness Form and Content of the local Plan as a Tool for the Quality of Life in Urban Area. Procedia Soc. Behav. Sci. 2016, 222, 897-906. [CrossRef]

28. Mouratidis, K. Urban planning and quality of life: A review of pathways linking the built environment to subjective well-being. Cities 2021, 115. [CrossRef]

29. Hedelin, B.; Gray, S.; Woehlke, S.; BenDor, T.K.; Singer, A.; Jordan, R.; Zellner, M.; Giabbanelli, P.; Glynn, P.; Jennj, K.; et al. What's left before participatory modeling can fully support real-world environmental planning processes: A case study review. Environ. Model. Softw. 2021, 143, 1-15. [CrossRef]

30. Hewitt, R.J.; Pera, F.A.; García-Martín, M.; Gaudry-Sada, K.H.; Hernández-Jiménez, V.; Bieling, C. Mapping adolescents' sense of place and perceptions of change in an urban-rural transition area. Environ. Manag. 2020, 65, 334-354. [CrossRef] [PubMed]

31. Özdemir, A. An approach on children's experiences of participatory planning. Cities 2019, 93, 206-214. [CrossRef]

32. Puolamäki, L. Tracing Cultural Landscape Values of Children with Participatory Geographic Information System. Eur. Countrys. 2017, 9, 375-396. [CrossRef]

33. Novotná, K.; Havelková, L. Mapování pocitů v okolí naší školy. Geografické Rozhledy 2018, 28, $24-27$.

34. Mäkinen, K.; Tyrväinen, L. Teenage experiences of public green spaces in suburban Helsinki. Urban For. Urban Green. 2008, 7, 277-289. [CrossRef]

35. Abbott-Chapman, J.; Robertson, M. Adolescents' Favourite Places: Redefining the Boundaries between Private and Public Space. Space Cult. 2009, 12, 419-434. [CrossRef]

36. Alarasi, H.; Martinez, J.; Amer, S. Children's perception of their city centre: A qualitative GIS methodological investigation in a Dutch city. Child. Geogr. 2016, 14, 437-452. [CrossRef]

37. Travlou, P.; Owens, P.E.; Thompson, C.W.; Maxwell, L. Place mapping with teenagers: Locating their territories and documenting their experience of the public realm. Child. Geogr. 2008, 6, 309-326. [CrossRef]

38. Gordon, E.; Elwood, S.; Mitchell, K. Critical spatial learning: Participatory mapping, spatial histories, and youth civic engagement. Childs Geogr. 2016, 14, 558-572. [CrossRef]

39. Czech Statistical Office. Available online: www.czso.cz (accessed on 7 October 2021).

40. South Moravian Region. Development Strategy of the South Moravian Region 2020. 2012. Available online: https://www.krjihomoravsky.cz/Default.aspx?ID=961\&TypeID=1 (accessed on 6 October 2021).

41. Hendl, J. Kvalitativní výzkum: Základní teorie, metody a aplikace, 4th ed.; Portál: Praha, Czech Republic, 2016; ISBN 978-80-262-0982-9. 
42. Amedeo, D.M.; Golledge, R.G. Environmental perception and behavioral geography. In Geography in America at the Dawn of the 21st Century; Gaile, G.L., Willmott, C.J., Eds.; Oxford University Press: Oxford, UK; New York, NY, USA, 2003; pp. 133-148. ISBN 0-19-823392-2.

43. Lee, C.H. Understanding rural landscape for better resident-led management: Residents' perceptions on rural landscape as everyday landscapes. Land Use Policy 2020, 94, 1-11. [CrossRef]

44. Seymour, M.; Wolch, J.; Reynolds, K.D.; Bradbury, H. Resident perceptions of urban alleys and alley greening. Appl. Geogr. 2010, 30, 380-393. [CrossRef]

45. Newell, J.P.; Seymour, M.; Yee, T.; Renteria, J.; Longcore, T.; Wolch, J.R.; Shishkovsky, A. Green Alley Programs: Planning for a sustainable urban infrastructure? Cities 2013, 31, 144-155. [CrossRef]

46. Seymour, M.; Trindle, T.B. Use dimensions of an alley revitalization project. Landsc. Res. 2015, 40, 586-592. [CrossRef]

47. Moreira, T.C.L.; de Oliveira, R.C.; Amato, L.F.L.; Kang, C.-M.; Saldiva, P.; Saiki, M. Intra-urban biomonitoring: Source apportionment using tree barks to identify air pollution sources. Environ. Int. 2016, 91, 271-275. [CrossRef]

48. Ruskule, A.; Nikodemus, O.; Kasparinskis, R.; Bell, S.; Urtane, I. The perception of abandoned farmland by local people and experts: Landscape value and perspectives on future land use. Landsc. Urban Plan. 2013, 115, 49-61. [CrossRef] 